\title{
Expression of Tumor Necrosis Factor Receptors in Normal Kidney and Rejecting Renal Transplants
}

\author{
Rafia S. Al-Lamki, Jun Wang, Jeremy N. Skepper, Sathia Thiru, Jordan S. Pober, \\ and John R. Bradley
}

\begin{abstract}
Departments of Medicine (RSA, JW, JRB) and Pathology (ST), University of Cambridge, Addenbrooke's Hospital, Cambridge; Multi-Imaging Centre (JNS), Department of Anatomy, University of Cambridge, Cambridge, United Kingdom; and The Boyer Center for Molecular Medicine and the Department of Pathology (JSP), Yale University School of Medicine, New Haven, Connecticut
\end{abstract}

\begin{abstract}
SUMMARY: Activation of the TNF signal transduction cascade is initiated by the interaction of TNF with either of two cell surface receptors, TNFR-1 and TNFR-2. The levels and regulation of expression of these two receptors has been extensively analyzed in cultured cells, but little is known of TNFR expression in situ. We analyzed the expression of TNFR-1 and -2 in normal human renal kidney and in renal transplants undergoing acute cellular rejection. Immunohistochemistry and immunogold electron microscopy indicated a strong expression of TNFR-1 on the endothelium of glomeruli of normal kidney. Immunogold colocalization for TNFR-1 and a marker of the trans-Golgi network (TGN-46) demonstrated TNFR-1 within the Golgi complex in endothelial cells in normal kidney, confirming our previous studies with cultured cells. TNFR-1 expression was lost in glomeruli from acutely rejecting kidney, but TNFR-1 was detected in abundance on infiltrating leukocytes in the interstitium of allografts with acute rejection. In contrast, TNFR-2 was demonstrated predominantly in epithelial cells of distal convoluted tubule (DCT) in acute rejection kidney near TNF-expressing leukocytes. TNF was absent in normal kidney, but present in rejecting allograft. TNF was found in infiltrating leukocytes and in adjacent tubular epithelial cells. In situ hybridization showed TNFR-1 mRNA within the endothelium of the glomeruli and of a few arterioles in normal kidney, whereas TNFR-2 mRNA was seen in tubular epithelial cells of the DCT in acute transplant rejection. These data reveal that there is both differential expression and regulation of the two TNF receptors in human kidney. (Lab Invest 2001, 81:1503-1515).
\end{abstract}

$T$ umor necrosis factor (TNF, also known as TNF- $\alpha$ ) is a major mediator of host defense reactions against infectious microbes (Le and Vilcek, 1987; Tartaglia et al, 1991) and also has been implicated as a mediator of inflammation associated with noninfectious causes (Fiers, 1991). The importance of TNF in human disease has recently been highlighted by the efficacy of strategies to reduce the activity of TNF in clinical studies. Treatment with anti-TNF antibodies or administration of soluble TNF receptors is effective in controlling disease activity in rheumatoid arthritis and Crohn's disease (O'Dell, 1999) and is likely to prove beneficial in other inflammatory conditions, including renal transplant rejection (Noel et al, 2000; Sahoo et al, 2000).

The biologic actions of TNF are initiated by binding of homotrimeric ligand to receptor polypeptides expressed on the surface of target cells. Two distinct receptors for TNF have been identified, respectively

Received July 11, 2001.

This work was supported by grants from the National Kidney Research Fund (United Kingdom) and from the National Institutes of Health (USA).

Address reprint requests to: Dr. Rafia S. Al-Lamki, Department of Medicine, University of Cambridge, Addenbrooke's Hospital, P.O. Box 157, Level 5, Hills Road, Cambridge CB2 2QQ, United Kingdom. E-mail: rsma2@hermes.cam.ac.uk designated as TNFR-1 (also known as p55 or CD120a) and TNFR-2 (also known as p75 or CD120b). Both receptors are widely expressed on various cultured cell types and cell lines, typically at a few thousand copies per cell (Vandenabeele et al, 1995). Most biologic responses have been attributed to signaling initiated by ligand binding to TNFR-1, but some responses (especially in T cells) have been ascribed to ligand binding to TNFR-2; the presence of TNFR-2 may also potentiate the responses mediated by TNFR-1, possibly through ligand binding and "passing" (Vandenabeele et al, 1995). Despite their putative interactions, there is only limited evidence for direct contact between the two TNF receptor types and, for the most part, they appear to localize in distinct subcellular compartments. Specifically, in cultured cells TNFR-2 is predominantly expressed on the plasma membrane, whereas TNFR-1 largely resides in the trans-Golgi with only a small subset of receptors appearing on the cell surface (Bradley et al, 1995; Jones et al, 1999). Both receptors also exist as soluble proteins, released from the cell membrane by the action of a metalloproteinase, probably identical to the TNF- $\alpha$-converting enzyme (TACE) (Reddy et al, 2000). Receptor shedding may be initiated by cell injury (Madge et al, 1999) or possibly inflammation, and shed receptors may act as competitive inhibitors of surface 
receptors, preventing TNF actions (Engelmann et al, 1990).

Almost all of the information about TNF receptor expression and localization has been derived from studies with cultured cells and little is known about the cellular distribution of TNFR-1 and TNFR-2 in whole tissue or about the subcellular distribution of these receptors in various cell types in vivo. It is also unknown what effect injury or inflammation has on these distributions within a tissue. In the present study, we have examined the expression of TNFR-1 and TNFR-2 in human kidney, both under normal conditions and during renal allograft rejection. We chose to focus our studies on acute cellular renal transplant rejection because this allowed us to prospectively collect fresh specimens (via diagnostic biopsies) from a well-defined group of patients in a setting where TNF has been implicated in pathogenesis (Noel et al, 2000; Sahoo et al, 2000). We find that receptor expression varies significantly among different cell types and is dramatically altered by the inflammatory process. These observations are discussed in the context of potential regulation of the kidney responses to TNF.

\section{Results}

Table 1 is a summary of TNFR-1 and TNFR-2 antigen expression on normal and allograft rejections. The results were graded semiquantitatively and scored as -, no labeling; +/-, occasional positive labeling ( $>2 \%$ of cells positive); + , weak labeling $(>5 \%$ of cells positive); ++ , intermediate labeling $(>10 \%$ of cells positive); +++ , strong labeling ( $>40 \%$ of cells positive); ++++ , very strong labeling $(>60 \%$ of cells positive).

\section{Hematoxylin and Eosin}

Hematoxylin and eosin-stained sections of normal human kidney from tumor resections showed normal histology with no pathologic changes (Fig. 1a). The nine allograft specimens showed a spectrum of changes ranging from early, to moderate, to severe acute cellular rejection. One of the allograft nephrectomies showed evidence of severe, ongoing acute rejection on a background of chronic rejection (Fig. 1, $b$ to $d$ ). The morphologic features of acute rejection included endothelialitis, tubulitis, interstitial edema, and infiltration by activated lymphocytes, macrophages, and eosinophils; the glomeruli were hypercellular secondary to infiltration by lymphocytes and macrophages. The tubules showed varying degrees of tubular epithelial cell degeneration and necrosis, and, particularly in the allograft specimens, proximal tubules were difficult to distinguish from distal tubules because of the loss of specialized features such as brush border. The most striking feature in the specimens with chronic rejection was a proliferative endarteritis in many of the arterioles, interlobular arteries, and arcuate arteries. In some nephrectomy specimens there was extensive protein reabsorption with abundant protein droplets.

\section{TNF Receptor Expression in Normal Kidney}

In the histologically normal kidney, TNFR-1 was detected in all glomeruli (Fig. 2a) and positive reaction product was mainly confined to the endothelium of the glomeruli (Fig. 2b). There was occasional weak staining for TNFR-1 on epithelial cells of distal convoluted tubules (DCT) but in general, little or no TNFR-1 was detected on renal epithelial or mesangial cells. Mod-

Table 1. TNF Receptor Expression in Normal Human Kidney and Renal Transplant Undergoing Acute Allograft Rejection

\begin{tabular}{|c|c|c|c|c|c|c|c|}
\hline & \multirow[b]{2}{*}{ Biopsies } & \multicolumn{2}{|c|}{ TNFR-1 } & \multicolumn{2}{|c|}{ TNFR-2 } & \multicolumn{2}{|c|}{ TNF } \\
\hline & & Glomeruli & Tubules & Glomeruli & Tubules & Glomeruli & Tubules \\
\hline \multirow{8}{*}{$\begin{array}{c}\text { Normal } \\
\text { human } \\
\text { kidney }\end{array}$} & 1. & ++ & - & - & $+1-$ & - & - \\
\hline & 2. & + & - & - & - & - & - \\
\hline & 3. & ++ & $+1-$ & - & $+1-$ & - & - \\
\hline & 4. & +++ & $+1-$ & - & $+1-$ & - & - \\
\hline & 5. & +++ & - & - & $+1-$ & - & - \\
\hline & 6. & +++ & - & - & - & - & - \\
\hline & 7. & ++ & - & - & - & - & - \\
\hline & 8. & ++ & - & - & $+1-$ & - & - \\
\hline \multirow{9}{*}{$\begin{array}{l}\text { Acute } \\
\text { rejection } \\
\text { kidney }\end{array}$} & 1. Early & $+1-$ & - & - & + & - & + \\
\hline & 2. Early & $+1-$ & - & - & - & - & $+1-$ \\
\hline & 3. Early & $+1-$ & - & - & + & - & + \\
\hline & 4. Moderate & $+1-$ & - & - & ++++ & - & ++ \\
\hline & 5. Moderate & $+1-$ & - & - & +++ & - & ++ \\
\hline & 6. Moderate & + & - & - & ++ & - & ++ \\
\hline & 7. Severe & - & - & - & +++ & - & +++ \\
\hline & 8. Severe & - & - & - & ++++ & - & ++++ \\
\hline & 9. Severe & - & - & - & ++++ & - & +++ \\
\hline
\end{tabular}

TNFR, tumor necrosis factor receptor.

Scores: - , no labeling; $+/-$, occasional positive labeling $(>2 \%) ;+$, weak labeling $(>5 \%) ;++$, intermediate labeling $(>10 \%) ;+++$, strong positive labeling $(>40 \%) ;++++$, very strong labeling $(>60 \%)$. 

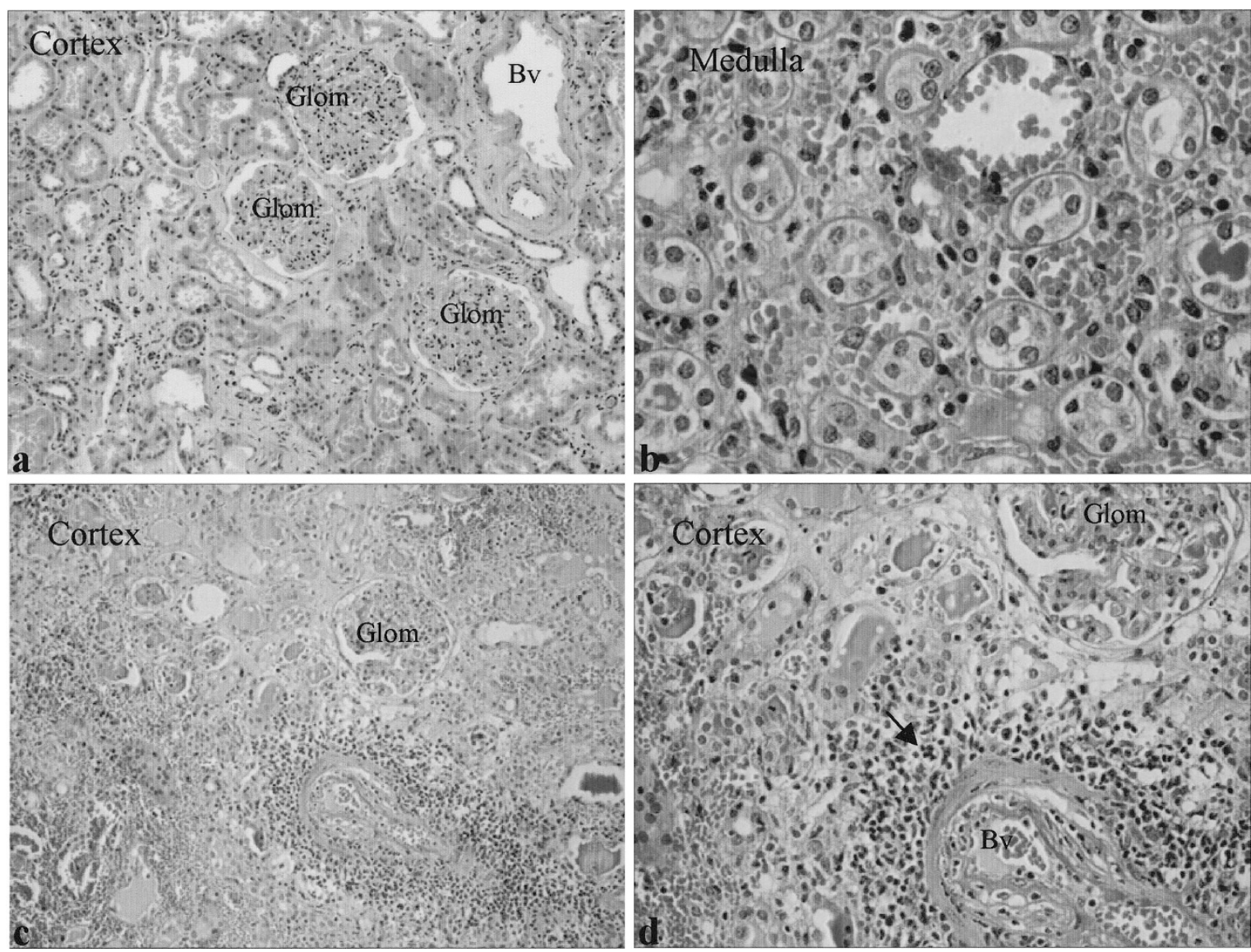

Figure 1.

Light micrographs of hematoxylin and eosin staining. a, Section of normal human kidney shows normal histology with no pathologic changes. Glom, glomeruli; $B V$, blood vessel. Section of severe allograft nephrectomy shows the changes in the medulla (b) and cortex (c and d). There is evidence of severe, ongoing acute rejection with a background of chronic rejection. The morphologic features include endothelialitis, tubulitis, interstitial edema, and infiltration by activated lymphocytes, macrophages, and eosinophils (arrow). The glomeruli are hypercellular after infiltration by lymphocytes and macrophages. The tubules show varying degrees of tubular epithelial cell degeneration and necrosis and, particularly in the severe allograft specimens, proximal tubules were difficult to distinguish from distal tubules because of the loss of specialized features such as brush border. The most striking feature in the specimens with chronic rejection was a proliferative endarteritis in many of the arterioles, interlobular arteries, and arcuate arteries $(B v)$. Original magnifications, $a, \times 55 ; b, \times 235 ; c, \times 22 ; d, \times 235$.

erate reaction for TNFR-1 was also evident at the luminal surface of endothelial cells (EC) of arterioles and peritubular capillaries. TNFR-1 labeling was not demonstrated in veins. No staining was seen on sequential sections of normal kidney when the primary antibody was replaced by isotype-matched irrelevant antibody (Fig. 2c). In addition, the identity of endothelium throughout the kidney and the preservation of the endothelium in renal veins was confirmed by labeling of biopsies with antibody reactive with von Willebrand (vWF), which showed intense labeling of all glomeruli, endothelium of blood vessels, and peritubular capillaries (Fig. 2d). Frozen sections from normal kidney stained with anti-vWF-fluorescein-isothiocyanate (FITC) (Fig. 2e) and anti-hTNFR-1 (Fig. 2f) showed colocalization of antibody binding mainly on the EC of glomerular endothelium (Fig. 2g). However, occasional cells within the glomeruli were TNFR-1-positive and vWF-negative. Accessibility and antigen presentation throughout the kidney was confirmed by staining using an antibody to MHC class I molecules (Fig. 2h). The pattern seen in normal kidney tissue incidentally resected for cancer was largely recapitulated in nor- mal kidneys harvested for transplantation. Specifically, sections of archive material from biopsies taken from donor kidneys during transplant operation immediately after reperfusion (time-zero biopsies) showed a similar distribution of staining for TNFR-1 in the glomeruli (Fig. 3). In general, there was less staining of TNFR-1 in archived time-zero biopsies compared with freshly frozen specimens; this difference is likely to indicate susceptibility of TNF receptors to the higher concentration of formaldehyde fixation (10\% formalin $>24$ hours) that these specimens had been exposed to. This signal could not be improved by alternative pretreatments.

The results of immunostaining were supported by in situ hybridization for mRNA localization. Specific strong staining for TNFR-1 mRNA was evident on all glomeruli in normal kidney (Fig. 4a) and had a distribution similar to TNFR-1 protein identified by immunohistochemistry (Fig. 4b), with moderate staining in the endothelium of small arterioles. No signal was observed after hybridization of normal kidney with a sense probe for TNFR-1 (Fig. 4c). 

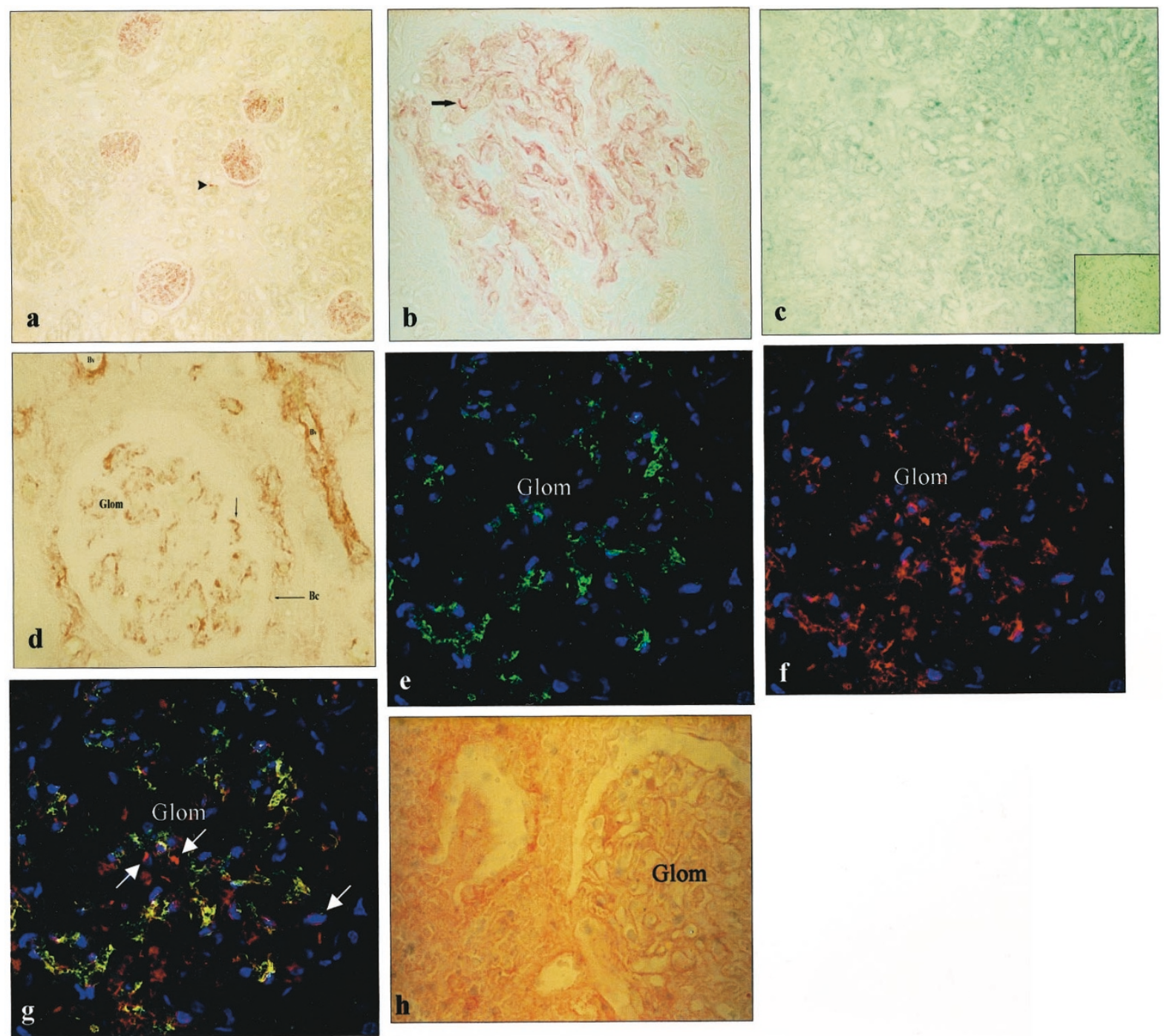

Figure 2.

A survey photomicrograph of paraffin-embedded section of normal human renal biopsy immunolabeled with mouse anti-hTNFR-1 and counterstained with $1 \%$ light green. A bright red reaction product of Vector Red is present on all glomeruli in the cortex (a), and occasional weak staining is evident on the distal convoluted tubule (DCT) in close proximity (arrowhead). A high-power view shows positive reaction mainly confined to the glomerular capillary wall (b, arrow); no staining is observed on sequential sections where the primary antibody is replaced by isotype-specific sera (negative control). c, inset, A high-power image shows a nonreactive glomeruli; the positive control shows a strong signal for anti-human Factor-VIII-related antigen (von Willebrand Factor, vWF) on the endothelium of blood vessels (BV) in close proximity (d). Confocal image of a frozen section of normal kidney colocalized for vWF-fluorescein-isothiocyanate (FITC) (e) and TNFR-1-(AlexaFluor 568) (f) revealed receptor-1 mainly in the endothelial cells (EC) of glomeruli $(\mathrm{g})$. However, there are cells in the glomeruli that are tumor necrosis factor receptor (TNFR)-1-positive and VWF-negative (arrows). Accessibility and antigen presentation throughout the kidney was confirmed by staining with antibody to major histocompatibility complex (MHC) Class I (W6/32) (h). Bc, Bowman's capsule; Glom, glomeruli. Original magnifications, a, $\times 22 ; b, \times 235 ; \mathrm{c}, \times 10 ; \mathrm{d}$ to $\mathrm{f}, \times 200 ; \mathrm{g}$ to $\mathrm{h}, \times 116$.

Immunogold electron microscopy was carried out to investigate the subcellular distribution of TNFR-1. Thin sections of normal kidney revealed gold labeling for TNFR-1 both on the surface and over the cytoplasm of EC in the glomerular endothelium (Fig. 5a). In the cytoplasm, the gold particles were observed individually and in clusters. Labeling for TNFR-1 was also evident on the surface and in the cytoplasm of a few visceral epithelial cells or podocytes in the glomeruli (Fig. 5b). Gold labeling was not detected in sections incubated with either omission of primary antibody or with isotype-specific primary antibody (negative control, data not shown), whereas labeling with antibody to $\mathrm{VWF}$ revealed numerous gold particles on the Wiebel-Palade bodies in the EC of the glomeruli capillary wall (Fig. 5c). We additionally investigated the distribution of TNFR-1 by double immunogold labeling with a second antibody to a protein found exclusively in the trans-Golgi network (TGN-46) (Prescott et al, 1997). TGN-46 and TNFR-1 colocalized within the Golgi complex in the EC of glomerular endothelium (Fig. $5 \mathrm{~d}$ ).

In contrast to our findings with TNFR-1, immunohistochemical staining of fresh frozen normal human kidney for TNFR-2 showed no positive reaction in the glomeruli, but a weak reaction was observed on a few epithelial cells of the proximal convoluted tubules (PCT)(Fig. 6a). Also, in contrast to TNFR-1, no reaction product for TNFR-2 was evident in archive time-zero biopsies (Fig. 6b). Immunogold labeling for TNFR-2 showed gold particles on the surface and a few 


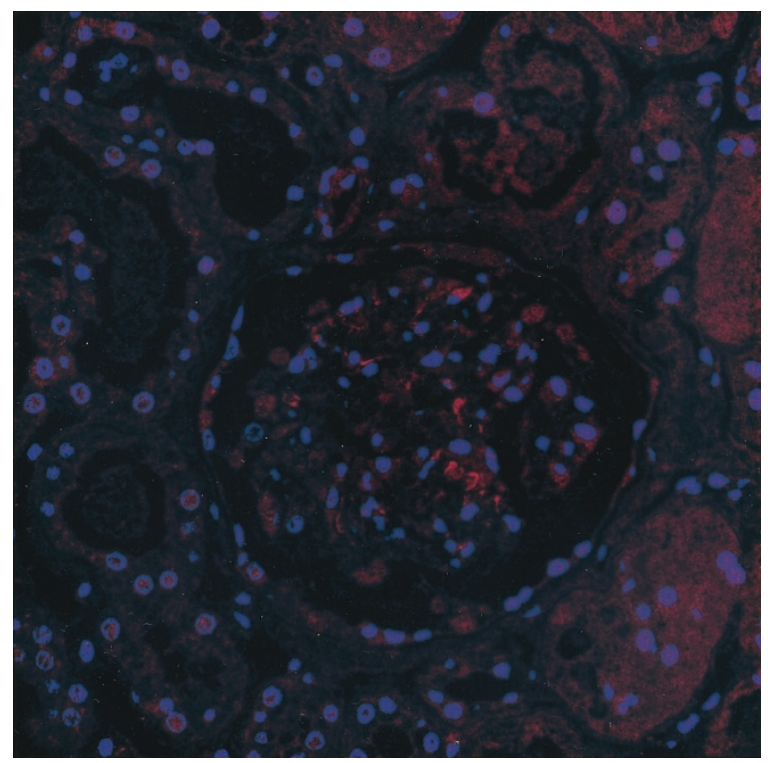

Figure 3.

Confocal image of a paraffin-embedded section of archive material from a time-zero biopsy from donor kidneys fixed in $10 \%$ formalin $>24$ hours. A moderate staining for TNFR- 1 is evident in glomeruli in the cortex. Original magnification, $\times 116$.

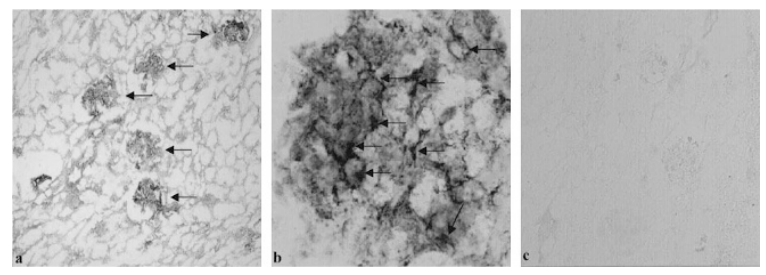

Figure 4.

TNFR-1 mRNA expression in the normal human kidney, detected by in situ hybridization using single-stranded digoxigenin-labeled antisense oligonucleotide probes and developed using sheep antidigoxigenin antibody conjugated to alkaline phosphatase $f(a b)_{2}$ and developed using an alkaline phosphatase substrate kit containing 5-brom-4-chloro-3-indoxyl phosphate/nitro blue tetrazolium chloride substrate solution (BCIP/NBT). a, The TNFR-1 mRNA is present in all glomeruli in the normal kidney (arrows). b, High magnification shows labeling on the endothelium (arrows) of the glomeruli. c, No staining is seen on the glomeruli after hybridization with a sense probe to TNFR-1. Original magnifications, a, $\times 22 ; \mathrm{b}, \times 235$; $\mathrm{c}, \times 55$.

randomly distributed in the cytoplasm of DCT (Fig. 6c). As expected, no mRNA expression for TNFR-2 was detected in the glomeruli or tubules in normal kidney (not shown). Positive controls labeled for $\alpha$-actin probe showed strong staining on both normal and allograft tissue (not shown).

In addition to examination of receptors, we also analyzed human kidneys for the presence of ligand, namely TNF. Frozen sections of normal kidney immunostained for TNF showed no significant staining (Fig. 7 , $a$ and b) but a strong signal was seen on positive control sections of human tonsils (Fig. 7c).

\section{TNF Receptor Expression in Acutely Rejecting Renal Allograft}

During allograft rejection, de novo expression of TNFR-2 was observed on tubular epithelial cells and the intensity of staining correlated with the severity of the rejection with respect to both the extent of mononuclear cellular tissue infiltrate and loss of specialized features such as the brush border in proximal tubules. As shown in Table 1, in samples with mild early rejection, TNFR-2 up-regulation was minimal. In moderate and severe allograft rejection, TNFR-2 immunostaining was found to be strong on descending loops of Henlé, DCT, and collecting ducts in the medulla (Fig. 8a). The pattern of labeling was cytoplasmic and mainly confined to the luminal portions of the cell (Fig. $8 a$, inset). In the cortex, a majority of epithelial cells of the PCT showed positive reaction in close proximity to the glomeruli, which were nonreactive (Fig. 8b). No staining for TNFR-2 was evident on sections stained with isotype-matched irrelevant antibody (Fig. 8, c and d). Strong labeling for TNFR-1 was observed only on infiltrating $\mathrm{CD}^{+} 8^{+}$macrophages and $\mathrm{CD}^{+}$lymphocytes in the interstitium, but TNFR-1 expression was diminished in glomeruli in most samples from allograft rejections.

The results of immunostaining of rejecting allografts were supported by immunogold electron microscopy. Sections with acute allograft rejection labeled for TNFR-2 revealed numerous gold particles in the cytoplasm of the epithelial cells in DCT and over the surface membrane (Fig. 8e). In other areas of the section, gold particles were observed on the surface of a few epithelial cells of PCT. However, extensive tubular damage in some areas of the section made interpretation very difficult.

These results were also supported by in situ hybridization. Strong signal for TNFR-2 mRNA was detected on epithelial cells of the DCT and, on a few PCT in the cortex, on sections from allograft kidney (Fig. 9, a and b). No mRNA was detected on sections hybridized with a sense probe to TNFR-2 (Fig. 9c) and on sections hybridized with antisense probe to TNFR-1 (not shown).

In all transplant allografts, TNF immunostaining was evident in a majority of the tubular epithelial cells in the cortex, on parietal cells of the Bowman's capsule, on some infiltrating leukocytes in the interstitium, and in the walls of numerous blood vessels (Fig. 10, a and b). TNF-expressing leukocytes were often near TNFexpressing tubular epithelial cells (Fig. 10c). No staining for TNF was observed in the glomeruli.

\section{Discussion}

In this study, the expression patterns of TNF receptors, TNFR-1 and TNFR-2, as well as TNF in normal human kidney and in renal allograft rejection have been examined by immunohistochemistry, in situ hybridization, and electron microscopy. Unexpectedly, we found evidence of limited receptor expression and an alteration of the pattern in rejection. TNFR-1 was found to be consistently expressed only in glomeruli of normal kidney, and TNFR-2, which is actually absent in normal kidney, was up-regulated in tubular epithelial cells of rejecting allografts. At the light microscopy level, it is difficult to appreciate the definite cellular 

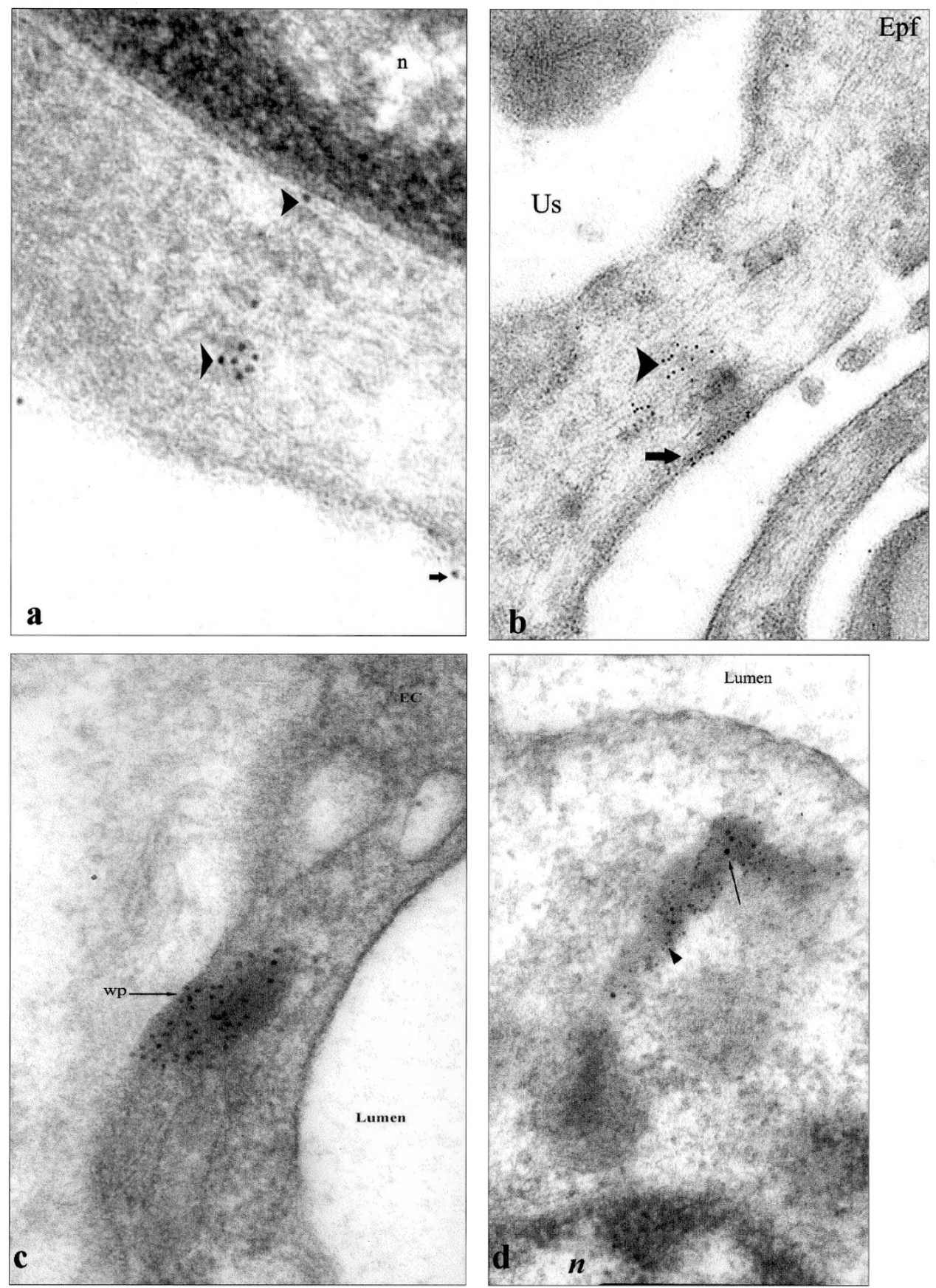

Figure 5.

Electron micrograph of a Lowicrly-HM20 section of normal human kidney immunostained for hTNFR-1 (10-nm gold). a, Labeling for TNFR-1 revealed occasional surface gold labeling in EC in glomeruli (arrow). A high frequency of gold particles for TNFR-1 is present over the cytoplasm (arrowheads). b, Surface (arrow) and cytoplasmic (arrowhead) gold labeling is also observed on a few visceral epithelial cell foot processes (Epf) in the glomeruli. c, Labeling for vWF shows numerous gold particles on Wiebel-Palade (wp) bodies in EC of glomeruli (positive control). d, Colocalization for hTNFR-1 (10-nm gold) and a trans-Golgi network marker (TGN-46, 5-nm gold) revealed receptor-1 (arrow) within the Golgi complex (arrowhead) in EC in the glomeruli. $n$, nucleus; Us, urinary space between Epf; EC, endothelial cells. Original magnifications, a, $\times 105,000 ; b, \times 21,000 ; c, \times 73,000 ; d, \times 52,000$.

localization of the staining because of the limitations of resolution. Thus, our ultrastructural study has for the first time demonstrated both the cellular and subcellular localization of the two TNF receptors in human kidney. Immunogold electron microscopy of normal human kidney confirmed that TNFR-1 predominantly localized to the Golgi complex in glomerular endothelial cells, consistent with our findings that TNFR-1 localizes to the Golgi in cultured endothelial cells (Bradley et al, 1995; Jones et al, 1999). Using immunogold electron microscopy, we were able to determine that the TNFR-1-positive and VWF-negative cells in the glomeruli in normal kidney were podocytes. Allograft rejection was associated with loss of TNFR-1 staining in the glomeruli as well as induction of TNFR-2 on tubular epithelial cells. The intensity of 

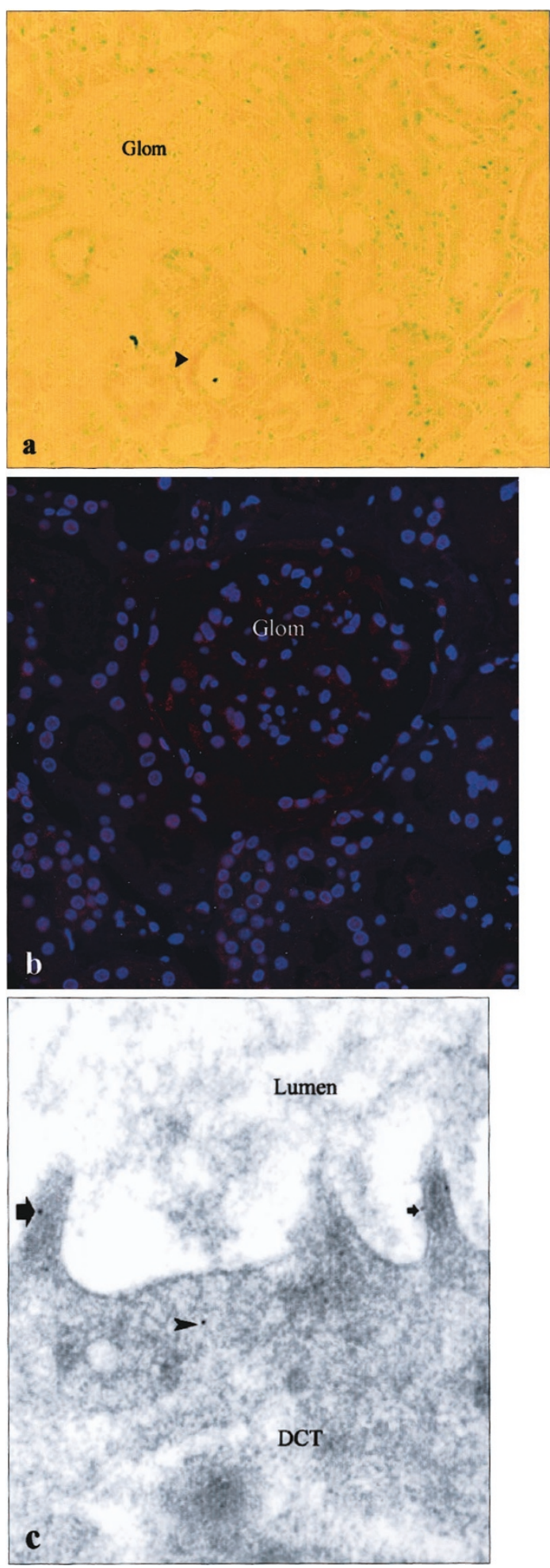

Figure 6.

a, Photomicrograph of a paraffin-embedded section of normal human kidney immunolabeled with mouse anti-hTNFR-2 and counterstained with $1 \%$ light green. No positive staining for TNFR-2 is present in the glomeruli (Glom), but a very weak reaction on a few epithelial cells of the proximal convoluted tubules (arrowhead) is apparent. b, In contrast to TNFR-1, no reaction product for TNFR-2 was evident in archive time-zero biopsies. c, Electron micrograph of Lowicrly-HM20 section of human allograft kidney immunogold-labeled for hTNFR-2 (10-nm gold) shows a few gold particles on the surface (arrow) of the short apical microvilli and in the cytoplasm (arrowhead) of the majority of EC of DCT. Original magnifications, $\mathrm{a}$ and $\mathrm{b}, \times 116 ; \mathrm{c}, \times 46,000$.
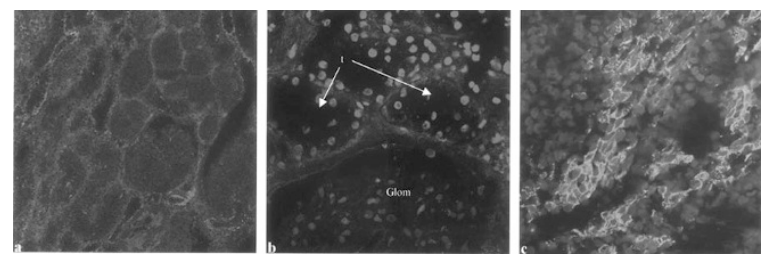

Figure 7.

Confocal image of a frozen section of normal human kidney stained with a mouse anti-TNF, followed by anti-mouse-FITC and mounted in Vectashield mountant containing 4', 6-diaminidino-2-phenylindole (DAPI). a, A low-power view shows no significant staining for TNF- $\alpha$. $b$, A high-magnification image shows absence of signal in glomeruli (Glom) and tubules $(t)$ in the cortex. C, A strong signal is observed on positive control sections of human tonsil. Original magnifications, a, $\times 100$; b, $\times 235 ; \mathrm{c}, \times 200$.

staining for TNFR-2 varied with respect to the severity of the rejection. In early, mild allograft rejections, the expression of TNFR-2 in tubular epithelial cells was considerably lower than in allografts with severe acute rejection. TNF-expressing tubular cells were often located near TNF-expressing leukocytes.

This observation suggests that up-regulation of TNFR-2 is characteristic of allograft rejection. TNF was absent from normal kidney and was expressed primarily on infiltrating leukocytes and on tubular epithelial cells on rejecting kidneys.

Previous studies have shown that most cell lines and primary tissues coexpress both TNF receptors, although TNFR-2 is preferentially expressed on cells of hematopoietic lineage (Santee and Owen-Schaub, 1996). It is possible that our failure to detect TNFR-1 on cells other than endothelium or any TNFR-2 expression in normal kidney is a question of sensitivity, that is, we were simply unable to detect low levels of protein expression. This seems unlikely because the same reagents work well on cultured cells and our immunostaining results were highly consistent with our in situ hybridization findings for mRNA expression. Nonspecific binding can be excluded because the isotype-specific irrelevant IgG antibodies or with nonimmune serum and the sense probes to the respective receptors did not bind these cells. In addition, the specificity of the in situ hybridization is supported by the reproducibility of the labeling pattern from slide to slide of each graft. We clearly see much higher levels of TNFR-1 on endothelium than other cell types in normal kidney. Our study also pointed to differential regulation of the two TNF receptors by the rejection process. These changes could result from changes in the rate of synthesis consistent with changes on the level of mRNA. A number of stimuli, including TNF, $\mathrm{IL}-1, \mathrm{IL}-10$, and tissue plasminogen activator, increase expression of TNFR-2 through transcriptional activation, whereas TNFR-1 is more commonly downregulated by these stimuli (Kalthoff et al, 1993; Winzen et al, 1992, 1993). The possibility of differential synthesis of the receptors is further supported by characterization of their promoter regions. The 5'regulatory region of TNFR-1 possesses features of a housekeeping promoter (Kemper and Wallach, 1993; Rothe et al, 1993a). The inducibility of TNFR-2 is supported by analysis of its promoter region, which 

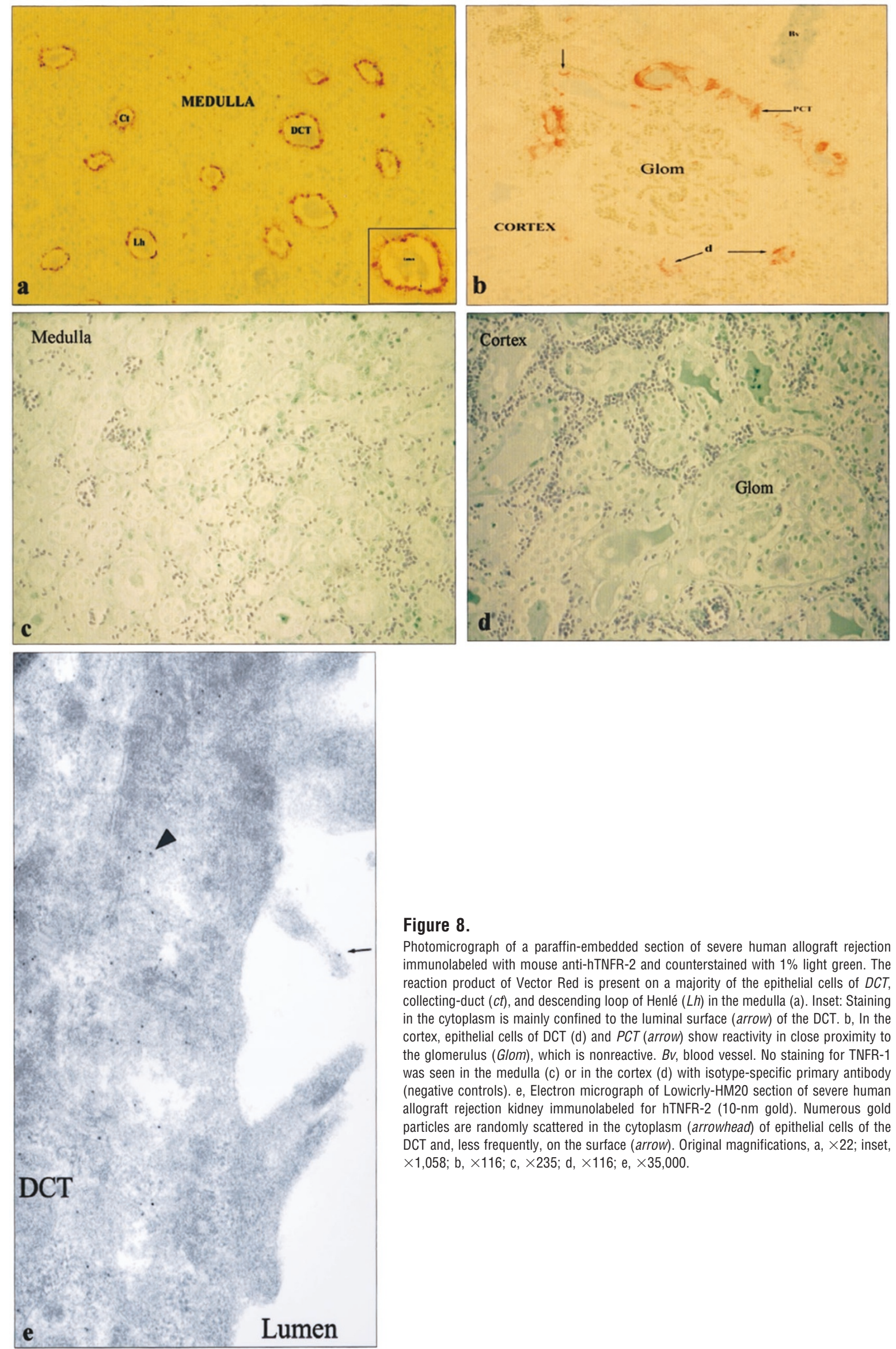

Figure 8.

Photomicrograph of a paraffin-embedded section of severe human allograft rejection immunolabeled with mouse anti-hTNFR-2 and counterstained with $1 \%$ light green. The reaction product of Vector Red is present on a majority of the epithelial cells of $D C T$, collecting-duct (ct), and descending loop of Henlé $(L h)$ in the medulla (a). Inset: Staining in the cytoplasm is mainly confined to the luminal surface (arrow) of the DCT. b, In the cortex, epithelial cells of DCT (d) and PCT (arrow) show reactivity in close proximity to the glomerulus (Glom), which is nonreactive. Bv, blood vessel. No staining for TNFR-1 was seen in the medulla (c) or in the cortex (d) with isotype-specific primary antibody (negative controls). e, Electron micrograph of Lowicrly-HM20 section of severe human allograft rejection kidney immunolabeled for hTNFR-2 (10-nm gold). Numerous gold particles are randomly scattered in the cytoplasm (arrowhead) of epithelial cells of the DCT and, less frequently, on the surface (arrow). Original magnifications, a, $\times 22$; inset, $\times 1,058 ; b, \times 116 ; c, \times 235 ; d, \times 116 ; e, \times 35,000$. 


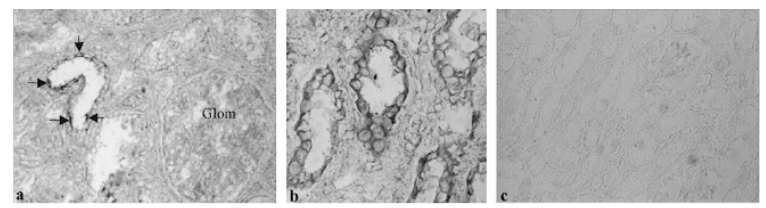

Figure 9.

Frozen section of severe human allograft rejection after hybridization using single-stranded digoxigenin-labeled antisense oligonucleotide probe to TNFR-2 and alkaline-phosphatase/BCIP/NBT. a, mRNA for TNFR-2 is evident on epithelial cells of the DCT (arrows). No message is evident in glomeruli (Glom) in close vicinity. b, A higher magnification shows staining confined to the tubular epithelial cells. c, No staining is seen on sections hybridized with a sense probe to TNFR-2 (negative control). Original magnifications, a, $\times 116$; $b$, $\times 353 ; \mathrm{c}, \times 55$.
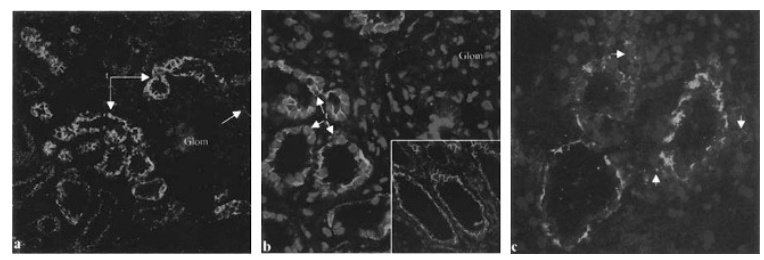

Figure 10.

Confocal image of a frozen section of severe human allograft rejection immunolabeled with mouse anti-hTNF, visualized using anti-mouse-FITC and mounted in Vectashield mountant containing DAPI. a, Low-power image showing immunoreaction in a majority of tubules $(t)$, a weak staining in parietal cells of the Bowman's capsule (arrow), but no staining is evident in the glomeruli (Glom). b, A high magnification shows tubular staining $(t)$ and an absence of staining in glomeruli (Glom). Inset: Strong staining of tubules in another area in the same section is evident. c, TNF-expressing leukocytes (arrows) were often near TNF-expressing tubular epithelial cells. Original magnifications, a, $\times 116$; b, $\times 200$; inset, $\times 200$; c, $\times 200$.

has a cAMP-response element and consensus elements for a number of transcription factors, including $\mathrm{NF} \kappa-\mathrm{B}, \mathrm{AP}-1, \mathrm{IRF}-1$, and GAS (Santee and OwenSchaub, 1996). An additional factor that is known to influence expression of TNF receptors is shedding from the cell surface. TNF binding proteins, later characterized as soluble forms of the two molecular species of cell surface TNF receptors, were first purified from normal human urine (Engelmann et al, 1990). The observation that both receptors are expressed in human kidney raises the possibility that soluble forms in the urine may arise in part through shedding from renal cells. Injurious agents are known to induce shedding of TNFR-1 from endothelial cells (Madge et al, 1999), and nitric oxide and hydrogen peroxide have been implicated in the activation of a metalloproteinase involved in shedding of TNFR-1 (Hino et al, 1999; Zhang et al, 2000). Thus, increased shedding, together with decreased transcription, could account for the loss of TNFR-1 from glomerular endothelial cells during rejection.

The relative roles of the two TNF receptors in mediating biologic effects of TNF is unclear, although studies in cultured cells and knockout mice suggest that they have both distinct and complementary functions. In susceptible cells, both receptors have been shown to mediate cytotoxicity. In endothelial cells, TNF effects are largely mediated by TNFR-1, but can be augmented by TNFR-2 (Mackay et al, 1993; Slowik et al, 1993), whereas proliferation of thymocytes and peripheral $\mathrm{T}$ cells appears to be largely mediated by TNFR-2 (Tartaglia et al, 1991, 1993). TNF receptordeficient mice support different roles for these receptors; for example, TNFR-1 -/- mice show significant defects in their defense against intracellular pathogens (Pfeffer et al, 1993; Rothe et al, 1993b), whereas TNFR-2 -/- mice remain responsive to TNF with somewhat reduced sensitivity (Erickson et al, 1994). The roles of the different TNF receptors in autoimmunity and transplantation are less well defined. In murine models of autoimmune diabetes, destruction of pancreatic beta cells appears to occur through TNFR1-dependent pathways (Kagi et al, 1999). Corneal transplantation between histocompatibility mismatched strains of gene-targeted knockout mice deficient in either TNFR-1, TNFR-2, or both receptors suggest that the two receptors play discrete roles in the rejection process (Yamada et al, 1999). TNFR-1 seems to be important for the rejection of minor alloantigen mismatched grafts, whereas TNFR-2 function appears to promote survival of major histocompatibility mismatched allografts. The differences that we have demonstrated in the expression of the two TNF receptors may be an important determinant of TNF responses and the outcome during transplant rejection. Our data showing restrictions of TNFR-1 to endothelium in the normal kidney may imply that the cell type is uniquely responsive to this cytokine. This may explain why TNF injection in vivo selectively increases plasminogen activator inhibitor-1 synthesis by glomerular endothelial cells, whereas mesangial cells respond instead to TGF- $\beta$ (Yamamoto and Loskutoff, 2000).

In natural inflammatory reactions, responses to TNF may be redundant with responses to the other cytokines, such as IL-1. IL-1 receptors are not known to be regulated, and responses to this cytokine are typically controlled by nonsignaling ligands (IL-1 receptor antagonist) or decoy receptors (IL-1R-2). The loss of TNFR-1 during allograft rejection may imply that the glomeruli have become less responsive to TNF. Alternatively, the major purpose of shed receptor may be to quench inflammation, and the diminished expression and synthesis (inferred by this reduction in mRNA) may actually imply a decrease in sensitivity to TNF, especially by infiltrating leukocytes.

The increased expression of TNF in acute cellular rejection but not in normal kidneys in our study supports the proposal that this cytokine is a mediator of the rejection process (Boucher et al, 1993; Imagawa et al, 1991). Cells of rejected organs undergo modulation of their functions and overexpression of TNF regulated proinflammatory proteins such as major histocompatibility complex (MHC) molecules, adhesion molecules, and chemokines for leukocytes (Briscoe et al, 1992; Krams et al, 1993). TNF could also contribute to procoagulant functions or cell death (Schmid et al, 1987).

The secretion of TNF in allograft rejection largely results from activation of immune cells triggered by alloantigen presentation to immunocompetent cells of 
host origin (Morel et al, 1993; Tracey and Cerami, 1993). Macrophages and/or lymphocytes have been reported in a peritubular distribution in early renal allograft rejection in humans and their numbers increase with severity of the graft rejection (Dooper et al, 1994). We hypothesize that TNF derived from immune cells that invade the cells of rejected organs may be the signal that induces TNFR-2 receptor expression on tubular epithelial cells associated with inflammatory conditions. If these receptors are shed, they could serve to diminish inflammation. Alternatively, TNF cytotoxicity may be a major effector pathway that leads to apoptosis in tubular epithelial cells in allograft rejections (Ito et al, 1995; Matsuno et al, 1996). TNF has been shown to induce DNA fragmentation (Schmid et al, 1987). In fact, apoptosis has been shown to occur as early as one week after transplantation in rat liver allografts and its incidence increases with severity of rejection (Meehan et al, 1997). TNF, through its membrane-bound form, may interact with TNFR-2 on tubular cells in allografts, as it does with Fas (CD95) (Porter et al, 2000), to activate cell death signaling pathway leading to apoptosis. This mechanism of cell death may be important for containing and eliminating target tubular epithelial cells in allograft rejections without harmful systemic effects (Decker et al, 1987). The pathogenetic importance of the TNFR-2, however, in allograft rejection is difficult to ascertain from our morphologic observations and therefore its participation in the induction and course of rejection remains to be elucidated.

Although the source of TNF in rejecting allografts is mainly considered to be infiltrating leukocytes, TNF may also be made by nonhematopoietic cells. TNF transcripts have been reported in astrocytes stimulated by LPS (Lieberman et al, 1989) and in some epithelial cell lines stimulated by IL-1 (Wuthrich et al, 1990). However, the failure of Morel et al (1993) to detect TNF mRNA in tubular epithelial cells in human allograft rejections suggests that these cells are not the source of TNF in the organ. Instead, the presence of TNF-expression in tubular epithelial cells near TNFexpressing leukocytes in our samples from allograft rejections suggests that epithelial cells take up leukocyte-secreted TNF.

In summary, the principal conclusions of this study are that the two TNF receptor types show a much more limited pattern of cellular expression in vivo than previously imagined and that the pattern of expression may be modulated by inflammation (eg, acute allograft rejection). These data suggest that TNF responsiveness in vivo can be regulated by receptor expression levels, an idea that can be tested in animal model.

\section{Materials and Methods}

Samples of normal human renal tissues were obtained from eight nephrectomy specimens removed for renal tumors. In addition five renal transplant biopsies taken during transplant operation immediately after reperfusion were analyzed (time-zero biopsies) and nine different samples of acute rejection were obtained from six biopsies and three allograft nephrectomy specimens. The allograft nephrectomies included early $(n=$ $3)$, moderate $(n=3)$, and severe $(n=3)$ acute cellular rejections. Informed, written consent was obtained from the Histopathology Department at Addenbrooke's Hospital, Cambridge, with the approval of the Tissue Bank Committee. Slices of tissue, not more than 1-mm thick, were taken from the cortex through to the medulla. The tissue was divided into three portions. One portion was fixed by immersion in $2 \%$ or 4\% formaldehyde (BDH Merck, Lutterworth, United Kingdom) in 0.1 M PIPES buffer, pH 7.6, for 4 hours at $4^{\circ} \mathrm{C}$ for light microscopy, and one portion for 1.5 hours at $4^{\circ} \mathrm{C}$ for transmission electron microscopy. The third portion was snap-frozen in liquid nitrogencooled isopentane and stored at $-70^{\circ} \mathrm{C}$ until use. Five-micrometer paraffin sections were placed on 3-aminopropyltriethoxy-saline (APES)-coated glass slides and used as required. In situ hybridization was carried out on $7-\mu \mathrm{m}$ cryostat sections, which were sectioned immediately before the hybridization procedure. A paraffin section from each batch of tissue was hematoxylin and eosin stained. On the basis of histologic findings, the tissue was classified as either normal with no pathologic changes or as acute cellular rejection.

\section{Light Microscopy}

Single Immunostaining for TNFR-1, TNFR-2, and $T N F-\alpha$. All incubations were carried out at room temperature in a humid chamber, unless otherwise stated. Paraffin sections from normal and transplant rejections were dewaxed in xylene and rehydrated through a descending series of ethanol concentrations. Sections were then washed in running tap water and in deionized water before incubation with $50 \mu \mathrm{g} / \mathrm{ml}$ proteinase-K (Roche Diagnostics, Welwyn Garden City, United Kingdom) in $0.1 \mathrm{M}$ Tris- $\mathrm{HCl}$ buffered saline (TBS) at $\mathrm{pH} 7.6$ for 10 minutes, and incubated with blocking buffer containing 10\% FCS to suppress nonspecific antibody binding. Excess blocking buffer was removed and sections were incubated overnight at $4^{\circ} \mathrm{C}$ in primary antibody: monoclonal mouse antihTNFR-1 (lgG 1 /Clone: 16803.7; R and D Systems Europe, Oxford, United Kingdom) or monoclonal mouse anti-hTNFR-2 (lgG $2 \mathrm{a} /$ Clone: 22221.311; $\mathrm{R}$ and D Systems) at 1:20 dilution in 10\% FCS at working concentration of $25 \mu \mathrm{g} / \mathrm{ml}$. After rinsing extensively with TBS, the sections were incubated for a further 45 minutes with goat anti-mouse antibodies conjugated to alkaline phosphatase (Sigma Chemical, Poole, United Kingdom) diluted 1:100 in blocking buffer. The sections were then rinsed thoroughly in TBS and in 0.1 M TBS, $\mathrm{pH} 8.4$, for 10 minutes. Antibody binding sites were visualized microscopically by incubation for 20 to 30 minutes with an alkaline phosphatase substrate kit (Vector Laboratories, Peterborough, United Kingdom) that uses Vector Red as its chromogen. The sections were then rinsed in deionized water, dehydrated in a series of ethanol solutions, cleared in xylene, and mounted in DePeX before viewing using a bright-field 
microscope (Nikon OPTIPHOT-2 with DMC 2.0 Microscope Camera, Surrey, United Kingdom), and Leica TCS-NT Confocal Laser Scanning Microscope (CLSM; Leica Microsystems, Milton Keynes, United Kingdom). The Vector Red reaction product is a bright red precipitate, which can be viewed with Texas Red excitation and emission filters. Vector Red can also be visualized directly with bright-field light microscopy.

Frozen sections from each batch of normal and transplant rejection tissue were additionally immunostained with mouse monoclonal anti-hTNF- $\alpha\left(\operatorname{lgG}_{1} /\right.$ Clone: 28401.111; $R$ and $D$ Systems) at 1:50 dilution in $10 \%$ FCS at a working concentration of $10 \mathrm{ug} / \mathrm{ml}$, and incubated at $4^{\circ} \mathrm{C}$ overnight. After rinsing in TBS, sections were incubated in anti-mouse-FITC (Dako, Bucks, United Kingdom) at 1:100 dilution in 10\% FCS for 45 minutes at room temperature. Sections were then rinsed in TBS, thoroughly washed in deionized water, and mounted in Vectashield mounting medium containing $1.5 \mu \mathrm{g} / \mathrm{ml}$ 4', 6-diaminidino-2-phenylindole (DAPI; Vector Laboratories) for DNA before viewing using a CLSM as previously described.

Controls included (a) omission of primary antibody and use of isotype-specific primary antibody or nonimmune serum as negative controls, (b) use of intrinsic positive control for macrophage (CD68; Clone PG-M1; Dako) and lymphocyte marker (CD3; Dako) cell lineage in transplant biopsies, (c) using antibody to Factor VIII-related antigen (vWf; Dako) and to MHC class-I histocompatibility complex (W6/32; Dako), and (d) $10 \%$ formalin-fixed, paraffin-embedded archive material from time-zero biopsies (taken during transplant operation) were stained for TNFR-1 and TNFR-2.

Combined Labeling for TNFR-1 and vWF. Frozen sections from each batch of normal kidney were incubated with $1: 20$ dilution $(25 \mu \mathrm{g} / \mathrm{ml})$ of mouse monoclonal anti-hTNFR-1 and 1:5,000 dilution of rabbit polyclonal anti-vWF in $10 \%$ FCS at $4^{\circ} \mathrm{C}$ overnight. After a thorough rinsing in TBS, the sections were incubated with anti-mouse Alexa Fluor 568 (Cambridge, Bioscience, Cambridge, United Kingdom) and anti-rabbit-FITC (Dako) diluted 1:100 in 10\% FCS for 45 minutes at room temperature.

Positive control included staining of frozen sections from human tonsil for TNF- $\alpha$. All sections were then rinsed in TBS, thoroughly washed in deionized water, mounted in Vectashield mounting medium containing DAPI, and viewed using CLSM as previously described.

\section{In Situ Hybridization}

For detection of specific mRNA in normal and allograft kidney, single-stranded antisense DNA oligonucleotide probes $5^{\prime}$ end labeled with digoxigenin specific for TNFR-1 (gb/M60275/HUMTNFRP, 476-515) and for TNFR-2 (gb/M55994/HUMTNFR2, 844-873) (MWGBiotech, Ltd., Milton, Keynes, United Kingdom) were used. Frozen sections, $7-\mu \mathrm{m}$ thick, were brought to room temperature and fixed in freshly prepared $4 \%$ formaldehyde (Sigma) in $0.1 \mathrm{M}$ PBS for 5 minutes at room temperature. After washing in two changes of
PBS, sections were treated with $5 \mu \mathrm{g} / \mathrm{ml}$ Proteinase-K (Roche Diagnostics) in PBS for 5 minutes at $37^{\circ} \mathrm{C}$. The sections were then incubated with $2 \mathrm{mg} / \mathrm{ml}$ glycine in PBS for 5 minutes and rinsed in $2 \times$ SSC for 5 minutes. Slides were then incubated at $37^{\circ} \mathrm{C}$ for 1 hour in hybridization buffer containing $1 \mathrm{~m}$ Tris- $\mathrm{HCl}, \mathrm{pH} 7.4$, $20 \times$ SSC, 0.05 m EDTA, $50 \%$ dextran sulfate, $50 \times$ Denhart's solution, formamide, and DEPC- $\mathrm{H}_{2} \mathrm{O}$. All reagents were of molecular grade from Sigma. Excess solution was removed and hybridization buffer containing $29 \mathrm{ng} / \mu \mathrm{l}(1.8 \mathrm{pmol} / \mu \mathrm{l})$ digoxigenin-labeled probes $(100 \mu l)$ was added to each section and incubated overnight at $37^{\circ} \mathrm{C}$ in a humidified chamber contained a filter paper soaked in DEPC- $\mathrm{H}_{2} \mathrm{O}$. After hybridization, the sections were washed with increasing stringency using SSC at the following concentrations; $2 \times$ SSC for 5 minutes at $37^{\circ} \mathrm{C}$; $0.2 \times$ SSC, $60 \%$ formamide, for 5 minutes at $37^{\circ} \mathrm{C}$ with two changes; $2 \times$ SSC for 5 minutes at room temperature with two changes; and finally in $100 \mathrm{~mm}$ Tris- $\mathrm{HCl}, 150 \mathrm{~mm} \mathrm{NaCl}$, $\mathrm{pH} 7.5$ (TBS) for 5 minutes at room temperature. The sections were then processed for immunologic detection. Briefly, the sections were blocked by incubation in TBS containing 1\% BSA (Sigma) for 30 minutes at room temperature. Sheep anti-digoxigenin antibody conjugated to alkaline phosphatase $\mathrm{f}(\mathrm{ab})_{2}(100 \mu \mathrm{l})$, diluted 1:200 in TBS-BSA was added to the sections and incubated in a humidified chamber at room temperature for 2 hours. After washings in TBS for 5 minutes with two changes, sections were rinsed in 0.1 M TBS, pH 9.4, for 10 minutes and antibody binding sites were visualized microscopically using alkaline phosphatase substrate kit containing 5-brom-4chloro-3-indoxyl phosphate/nitro blue tetrazolium chloride solution (BCIP/NBT; Sigma) as a substrate. Additional controls to confirm specificity of probe binding included using oligonucleotide cocktails of digoxigenin-labeled $\alpha$-actin probe from $\mathrm{R}$ and $\mathrm{D}$ Systems and negative controls included incubation of sections with a sense probe to either of the TNF receptors-1 and -2 (MW Biotech-AG).

\section{Electron Microscopy}

Freeze Substitution and Low-Temperature Embedding for Immunocytochemistry. Tissues fixed in $2 \%$ or $4 \%$ formaldehyde were cryoprotected in $30 \%$ propylene glycol for 1 hour at $4^{\circ} \mathrm{C}$. They were frozen in melting propane cooled in liquid nitrogen, substituted against methanol containing $0.1 \%$ uranyl acetate at $-90^{\circ} \mathrm{C}$ for 24 hours, at $-70^{\circ} \mathrm{C}$ for 24 hours, and at $-50^{\circ} \mathrm{C}$ for 24 hours. The tissue was then impregnated with Lowicryl HM 20 over a period of 3 days and the resin was polymerized by ultraviolet irradiation at a temperature of $-50^{\circ} \mathrm{C}$. Ultrathin sections $(40-50 \mathrm{~nm})$ were cut on a Leica Ultracut-S (Leica, Vienna, Austria) ultramicrotome and mounted on Formvar-coated nickel grids.

Single Immunogold Labeling for TNFR-1 or TNFR-2. The grids were incubated, section down, for 1.5 hours at room temperature in blocking buffer containing $10 \%$ FCS in TBS to suppress nonspecific antibody 
binding. Excess blocking buffer was removed and sections were incubated overnight, at room temperature, with either mouse anti-hTNFR-1 or mouse antihTNFR-2 diluted in blocking buffer at a final concentration of $100 \mu \mathrm{g} / \mathrm{ml}$. After rinsing extensively with TBS, the grids were incubated for 1 hour at room temperature with goat anti-mouse-10 nm colloidal gold particles (British Biocell, Cardiff, United Kingdom) diluted 1:100 in the blocking solution. After thorough rinsing in TBS and in double-distilled water, the grids were contrast-stained with uranyl acetate and lead citrate for 3 seconds each. Grids were then viewed in a Philips CM 100 electron microscope at an accelerating voltage of $80 \mathrm{kV}$.

Combined Immunogold Labeling for TNFR-1 and the Trans-Golgi Network Marker (TGN-46). After labeling with mouse anti-hTNFR-1, some grids were incubated further with sheep polyclonal anti-hTGN-46 (a generous gift from Dr. Paul Luzio, Cambridge Institute for Medical Research, Cambridge, United Kingdom) diluted 1:5 in blocking buffer overnight at room temperature. After thorough rinsing in TBS, the grids were incubated with donkey anti-sheep-5 $\mathrm{nm}$ colloidal gold particles (British Biocell) diluted 1:100 in blocking buffer for 1 hour at room temperature. Sections were then rinsed in TBS and in double-distilled water, and viewed as described previously.

\section{Acknowledgements}

The authors thank Ms. Janet Powell for her skillful technical assistance and Dr. Zainab Salim for typing the manuscript. Many thanks also are extended to Dr. Paul Luzio, CIMR, Cambridge, for providing the antihTGN-46 antibody and to the Department of Histopathology at Addenbrooke's hospital for providing human kidney tissue. Grateful acknowledgment also is made to Mr. Chris Burton and Mr. Ian Bolton of Cambridge University for their assistance in preparation of the illustrations and to Dr. Tao Wang for her help with the in situ hybridization technique. Ultrastructural studies were carried out at the MultiImaging Centre established in part by a grant from the Wellcome Trust.

\section{References}

Boucher D, Gogusev J, and Droz D (1993). Expression of IL6 and TNF-alpha in normal and pathological kidney. CR Seances Soc Biol Fil 187:425-428.

Bradley JR, Thiru S, and Pober J (1995). Disparate localisation of 55-kd and 75-kd tumor necrosis factor receptors in human endothelial cells. Am J Pathol 146:27-32.

Briscoe DM, Pober JS, Harmon WE, and Cotran RS (1992). Expression of vascular cell adhesion molecule-1 in human renal allografts. J Am Soc Nephrol 3:1180-1185.

Decker T, Lohmann-Matthes ML, and Gifford GE (1987). Cell-associated tumor necrosis factor (TNF) as a killing mechanism of activated cytotoxic macrophages. J Immunol 138:957-962.

Dooper IM, Hoitsma AJ, Maass CN, Assmann KJ, Tax WJ, Koene RA, and Bogman MJ (1994). THe extent of peritubular
CD14 staining in renal allografts as an independent immunohistological marker for acute rejection. Transplatation 58: 820-827.

Engelmann H, Novick D, and Wallach D (1990). Two tumor necrosis factor-binding proteins purified from human urine: Evidence for immunological cross-reactivity with cell surface tumor necrosis factor receptors. J Biol Chem 265:15311536.

Erickson SL, de Sauvage FJ, Kikly K, Carver-Moore K, Pitts-Meek S, Gillett N, Sheehan KC, Schreiber RD, Goeddel DV, and Moore MW (1994). Decreased sensitivity to tumornecrosis factor but normal T-cell development in TNF receptor-2-deficient mice. Nature 372:560-563.

Fiers W (1991). Tumor necrosis factor: Characterization at the molecular, cellular and in vivo level. FEBS Lett 285:199-212.

Hino T, Nakamura H, Abe S, Saito H, Inage M, Terashita K, Kato S, and Tomoike H (1999). Hydrogen peroxide enhances shedding of Type 1 soluble tumor necrosis factor receptor from pulmonary epithelial cells. Am J Respir Cell Mol Biol 20:122-128.

Imagawa DK, Larsen CP, and Morris PJ (1991). The role of tumour necrosis factor in allograft rejection. Transplantation 51:57-62.

Ito H, Kasagi N, Shimori K, Osaki M, and Adachi H (1995). Apoptosis in the human allografted kidney: Analysis by terminal deoxynucleiotidyl transferase-mediated DUTP-botin nick end labeling. Transplantation 60:794-798.

Jones SJ, Ledgerwood EC, Prins JB, Galbraith J, Johnson DR, Pober JS, and Bradley JR (1999). TNF recruits TRADD to the plasma membrane but not the trans-Golgi network, the principal subcellular location of TNF-R1. J Immunol 162: 1042-1048.

Kagi D, Ho A, Odermatt B, Zakarian A, Ohashi PS, and Mak TW (1999). TNF receptor 1-dependent beta cell toxicity as an effector pathway in autoimmune diabetes. J Immunol 162: 4598-4605.

Kalthoff H, Roeder C, Brockhaus M, Thiele HG, and Schmiegel W (1993). Tumor necrosis factor (TNF) up-regulates the expression of p75 but not p55 TNF receptors, and both receptors mediate independently of each other, upregulation of transforming growth factor alpha and epidermal growth factor receptor mRNA. J Biol Chem 268:2762-2766.

Kemper O and Wallach D (1993). Cloning and partial characterization of the promoter for the human p55 Tumor necrosis factor (TNF) receptor. Gene 134:209-216.

Krams SM, Ascher NL, and Martinez OM (1993). New immunologic insights into mechanisms of allograft rejection. Gastroenterol Clin North Am 22:381-400.

Lieberman AP, Pitha PM, Shin HS, and Shin ML (1989). Production of tumor necrosis factor and other cytokines by astrocytes stimulated with lipopolysaccharide or a neurotropic virus. Proc Natl Acad Sci USA 86:6348-6352.

Le $\mathrm{J}$ and Vilcek $\mathrm{J}$ (1987). Tumor necrosis factor and interleukin 1: Cytokines with multiple overlapping biological activities. Lab Invest 56:234-248.

Mackay F, Loetscher H, Stueber D, Gehr G, and Lesslauer W (1993). Tumor necrosis factor $\alpha$ (TNF $\alpha$ )-induced cell adhesion to human endothelial cells is under dominant control of one TNF receptor type, TNF-R55. J Exp Med 177:1277-1286. 
Madge LA, Sierra-Honigmann MR, and Pober JS (1999). Apoptosis-inducing agents cause rapid shedding of tumor necrosis factor receptor 1 (TNFR1). J Biol Chem 274:1364313649.

Matsuno $H$, Sasaki K, Nakagawa $Y$, Ishikawa $T$, Oishai $A$, Inagaki M, Saito S, Yagi, T, liaisa M, Tanaka N, and Orito $\mathrm{K}$ (1996). Apoptosis in human Kidney allograft. Tranpl Proc 28:1226-1227.

Meehan SM, McCluskey RT, Pascual M, Preffer FI, Anderson P, Scholssman SF, and Colvin RB (1997). Cytotoxicity and apoptosis in human renal allografts: Identification, distribution, and quantification of cells with a cytotoxic granule protein GMP-17 (TIA-1) and cells with fragmented nuclear DNA. Lab Invest 76:639-649.

Morel D, Normand E, Lemoine C, Merlio J-P, Velours J, Asteir T, Bonnet F, Aparicio M, Potaux L, and Bloch B (1993). Tumor necrosis factor alpha in human kidney transplant rejection: Analysis by in situ hybridization. Transplantation 55:773-777.

O'Dell JR (1999). Anticytokine therapy: A new era in the treatment of rheumatoid arthritis? N Engl J Med 340:310312.

Noel C, Copin MC, Hazzan M, Labalette M, Susen S, Lelievre G, and Dessaint JP (2000). Immunomodulatory effect of pentoxifylline during human allograft rejection: Involvement of tumor necrosis factor-alpha and adhesion molecules. Transplantation 69:1102-1107.

Pfeffer K, Matsuyama T, Kundig TM, Wakeham A, Kishihara K, Shahinian A, Wiegmann K, Ohashi PS, Kronke M, and Mak TW (1993). Mice deficient for the $55 \mathrm{kd}$ tumor necrosis factor receptor are resistant to endotoxic shock, yet succumb to $L$. monocytogenes infection. Cell 73:457-467.

Porter CJ, Ronan JE, and Cassidy MJ (2000). Fas-fas-ligand antigen expression and its relationship to increased apoptosis in acute renal transplant rejection. Transplantation 69: 1091-1094.

Prescott AR, Lucocq JM, James J, Lister JM, and Ponnambalam S (1997). Distinct compartmentalization of TGN46 and b1, 4-galactosyltransferase in HeLa cells. Eur J Cell Biol 72:238.

Reddy P, Slack JL, Davis R, Ceretti DP, Kozlosky CJ, Blanton RA, Shows D, Peschon JJ, and Black RA (2000). Functional analysis of the domain structure of tumor necrosis factor- $\alpha$ converting enzyme. J Biol Chem 275:14608-14614.

Rothe J, Bluethmann H, Gentz R, Lesslauer W, and Steinmetz M (1993a). Genomic organization and promoter function of the murine tumor necrosis factor receptor beta gene. Mol Immunol 30:165-175.

Rothe J, Lesslauer W, Lotscher H, Lang Y, Koebel P, Kontgen $F$, Althage A, Zinkernagel R, Steinmetz $M$, and Bluethmann $H$ (1993b). Mice lacking the tumor necrosis factor receptor 1 are resistant to TNF-mediated toxicity but highly susceptible to infection by Listeria monocytogenes. Nature 364:798-801.

Sahoo S, Kang S, Supran S, Saloman R, Wolfe S, and Freeman RB (2000). Tumor necrosis factor genetic polymorphisms correlate with infections after renal transplantation. $69: 880-884$
Santee SM and Owen-Schaub LB (1996). Human tumor necrosis factor receptor $\mathrm{p} 75 / 80$ (CD120b) gene structure and promoter characterization. J Biol Chem 271:21151-21159.

Schmid DS, Hornung R, Mcgrath KM, Paul N, and Ruddle NH (1987). Target cell DNA fragmentation mediated by lymphotoxin and TNF. Lymphokine Res 6:195-202.

Slowik MR, De Luca LG, Fiers W, and Pober JS (1993). Tumor necrosis factor activates human endothelial cells through the p55 tumor necrosis factor receptor, but the p75 receptor contributes to activation at low tumor necrosis factor concentration. Am J Pathol 143:1724-1730.

Tartaglia LA, Goeddel DV, Reynolds C, Figari IS, Weber RF, Fendly BM, and Palladino MA Jr (1993). Stimulation of human T-cell proliferation by specific activation of the $75 \mathrm{kDa}$ tumor necrosis factor receptor. J Immunol 151:4637-4641.

Tartaglia LA, Weber RF, Figari IS, Reynolds C, Palladino MA Jr, and Goeddel DV (1991). The two different receptors for tumor necrosis factor mediate distinct cellular responses. Proc Natl Acad Sci USA 88:9292-9296.

Tracey KJ and Cerami A (1993). Tumour necrosis factor, other cytokines, and disease. Annu Rev Cell Biol 9:317-343.

Vandenabeele P, Declercq W, Beyaert R, and Fiers W (1995). Two tumour necrosis factor receptors: Structure and function. Trends Cell Biol 5:392-398.

Winzen R, Wallach D, Engelmann H, Nophar Y, Brakebusch C, Kemper O, Resch K, and Holtmann H (1992). Selective decrease in cell surface expression and mRNA level of the $55-\mathrm{kDa}$ tumor necrosis factor receptor during differentiation of HL-60 cells into macrophage-like but not granulocyte-like cells. J Immunol 148:3454-3460.

Winzen R, Wallach D, Kemper O, Resch K, and Holtmann H (1993). Selective up-regulation of the 75-kDa tumor necrosis factor receptor and its mRNA by TNF and IL-1. J Immunol 150:4346-4353.

Wuthrich RP, Glimcher LH, Yui MA, Jevnikar AM, Dumas SE, and Kelley VE (1990). MHC class II, antigen presentation and tumor necrosis factor in renal tubular epithelial cells. Kidney Int 37:783-792.

Yamada J, Streilein JW, and Dana MR (1999). Role of tumor necrosis factor receptors TNFR-1 (P55) and TNFR-II (P75) in corneal transplantation. Transplantation 68:944-949.

Yamamoto K and Loskutoff, DJ (2000). Expression of transforming growth factor-beta and tumor necrosis factor-alpha in the plasma and tissue of mice with lupus nephritis. Lab Invest 80:1561-1570.

Zhang Z, Kolls JK, Oliver P, Good D, Schwarzenberger PO, Joshi MS, Ponthier JL, and Lancaster JR (2000). Activation of tumor necrosis factor-alpha-converting enzyme-mediated ectodomain shedding by nitric oxide. J Biol Chem 275: 15839-15844. 